Academic City University College - Accra Ghana

Society for Multidisciplinary \& Advanced Research Techniques (SMART) Africa

Tony Blair Institute for Global Change

FAIR Forward - Artificial Intelligence for All - Deutsche Gesellschaft für Internationale Zusammenarbeit (GIZ) GmbH

Accra Bespoke Multidisciplinary Innovations Conference (ABMIC)

\title{
Problems and Prospects of Integrating ICT in Geography and Environmental Sciences
}

\author{
Aladelokun, Adeniji Olawale (Ph.D) \& Ayodele, Michael Babatope \\ Department of Geography, \\ Bamidele Olumilua University of Education, Science and Technology, \\ Ikere-Ekiti, Ekiti State, Nigeria \\ E-mail: silvaniji1@gmail.com; ayodelemichael@coeikere.edu.ng \\ Phones: +2348062814393; +2347032513974
}

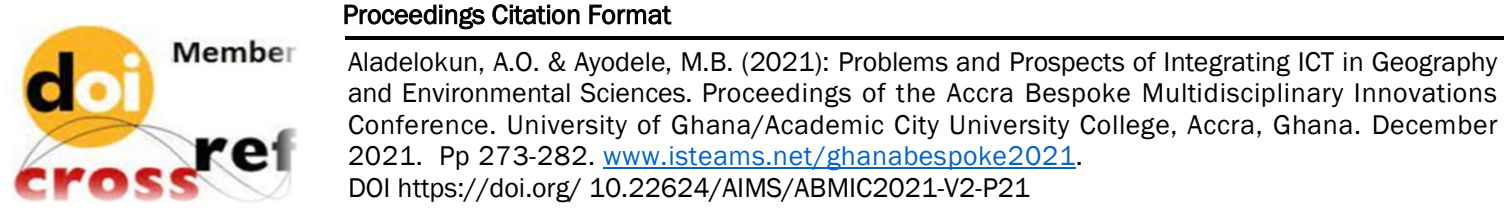




\title{
Problems and Prospects of Integrating ICT in Geography and Environmental Sciences
}

\author{
Aladelokun, Adeniji Olawale (Ph.D) \& Ayodele, Michael Babatope
}

\begin{abstract}
No doubt, the entire world is gaining momentum into digital media information. This is making Information and Communication Technologies (ICTs) an important aspect of the development. Presently, geography and environmental sciences in Nigeria is experiencing a major transformation in terms of access, equity, and quality which is highly influenced by the integration of ICTs. In other words, the introduction of ICTs into the discipline has serious implications especially in dealing with the key issues of access, equity, management, efficiency, pedagogy and quality. The optimal utilization of opportunity arising from the integration of ICTs presents a serious challenge to the discipline of geography and environmental sciences especially in the areas of data collection, management and analysis. The concern of this paper, therefore, is the ways in which ICTs is integrated into the discipline, the attendant prospects, and the challenges posed by the integration. Literature search of information from articles from Google scholar, academia, libraries, etc. coupled with personal survey research using telephone interview are the major sources of information. Results reveal, that the field of study is experiencing a serious threat in spite of the introduction of ICTs. This results from the way in which the ICTs has been conceptualized into the field of study - ideas of positivist and empiricist science are embraced while geographical knowledge based on humanists and realist approaches to science have been neglected. However, it is suggested that especially in the area of data collection, a holistic approach should be considered. Tools that will enhance collection of data related to field of study should be developed and not just for a particular variable. Also, Government should properly fund ICTs research and provide institutions with up-to-date technologies for development and innovation, and teachers should ensure participation in training provided by institutions' management, self-enroll or access training on internet resources.
\end{abstract}

Keywords: Education, Geography and Environmental Sciences, ICT

\section{INTRODUCTION}

The term development touches every aspect of human endeavour. Over time, Information Communication Technologies (ICT) have played significant role in Education. ICT role surpasses just ensuring improvement of knowledge and skills; it also forms the basis for innovation and economic development (Mbodila and Kikunga, 2012). One of such impact is in the application of ICT to teaching, learning and praxis, is the field of Geography and Environmental Sciences. However, proper integration of ICT has not been experienced in most developing nations of the world. This is owed to factors such as; institutional development, poor infrastructure, bad governance, lack of will to accept change, and poor implementation of policies to mention a few (Nyandiere, 2006; World Bank, 2009; Mbodila, Jones and Muhandji, 2013). 
The term ICTs has often been used to refer to the convergence of audiovisual and networks (telephone, computer) through a link system. It also encompasses all communication devices such as radio, television, cell phones, computers, network hardware and other appliances (Kondra, 2020; Ololube, Ubogu and Ossai 2011). It also encompasses all computer-based activities that derives from the convergence of disciplines which includes micro-electronics, computing, and telecommunications that have influenced the reorganization of the processes involved in production, distribution and circulation in the society. As periods emerge, powerful tools have been developed with the use of ICTs to enhance sharing of knowledge and information (Gadzama, Katuka, Dalhatu, Abali, and Maigana, 2016).

As new technologies emerge in the ICT applications, they have not been properly integrated to the teaching, learning and praxis of Geography and Environmental Sciences. It is on this note, this paper attempts to trace the development of Geography and ICT in Nigeria, examine the prospects of integrating ICT to the field of Geography and Environmental Sciences while considering the challenges.

\section{DEVELOPMENT OF GEOGRAPHY AND ENVIRONMENTAL SCIENCES IN NIGERIA}

Geography and environmental sciences on the other hand as field of academic and professional disciplines have been around in Nigeria for quite some time. It came into limelight at the University College, Ibadan as an affiliate of the University College of London in the year 1948. Since then, it has continued to experience shifts in techniques and pedagogical methodologies and has developed from a singular Department of Geography in 1948 to over more than hundreds of Geography Department up to date in private universities, public universities and colleges of education in Nigeria.

There have also been different ideologies in explaining the stages of growth in the field of Geography in Nigeria. For instance, Okpala (1990) gave three (3) stages to the chronological advancement of Geography as a discipline from the colonial era to post-civil war of 1960's. According to him, the First Era which is the colonial era existed in the 1800s to 1950s. Precisely in the second half of the 19th century, geographical education started in Nigeria and became one of the general subjects in most primary schools which produced court clerks, interpreters for the colonial government. Shortly before independence, the West African Examination Council (WAEC) was formed and geography was among the major subjects.

In the 1970 s to 1980 s the civil war in Nigeria led to a rethinking of the role of education, therefore the National Policy on Nigeria Education came up in 1977 and revised in 1981. These notable developments significantly influenced geographical studies in Nigeria. Okpala (1990) also noted that with a national policy formulated, each discipline planned its content and learning experiences leading to acquisition of knowledge, attitudes, and skills required for effective living in Nigeria. Hence, there has been a tremendous radical shift in vision, mission and philosophy in order to groom and train geographers in different capacities occasioned by the establishment of geography as a course of study in the the University College, Ibadan since 1948.

From another point of view Geography has been explained as evolving or changing from planning stage to the stage of professionalism (Ojo, 1978). The planning state (colonial period) 19481970 was a period of the old Geography or London School of Thought, brought by the expatriates and later trained few Nigerian geographers such as Prof. A.L. Mabogunje who was recruited as 
an Assistant Lecturer at the University College, Ibadan in 1958. At this period, the geographic philosophy on which the Ibadan programme was based was ideographic which was reflected in the original essay written by graduating students and the trend of the philosophy has been changing through space and time to scientific and quantitative approach to solve spatial problems.

At the second stage (Indigenization Era) which was from 1961-1970 significant changes were experienced in the philosophy and teaching of Geography in most Nigerian universities. At this time, many Nigerians have already acquired higher degrees in geography with Ph.D. and this qualified them to teach in various capacities such as undergraduate and postgraduate levels in the university. Likewise, the influence of indigenous geographers has started dominated. Nigerians had taken over the chairmanship of the departments of geography in all the universities by the year 1968 with the exception of Ahmadu Bello University, Zaria who still had the traces of foreign scholars. The Consolidation state which is the third stage (1971-1980) marked great achievement in the development of geography and environmental sciences. Nigerian geographers had started participating actively at the International Geographical Union, it grew from a membership of 40 teachers in 1955 to over 500 geographers in 1980 and beyond. Geography was also seen as a major tool for effective planning of the country, therefore the need for well trained geographers to provide the required man-power for spatial planning (Sada, 1987).

At the professional stage (1980 upward) there was re-organization and designing and development of new related courses such as planning and design. Some departments changed their names from the department of geography to department of geography and planning science in University of Calabar, geography and environmental management, University of PortHarcourt and Ilorin and department of geography and resource management, Osun State University. At this time a new curriculum thus came into operation, during this period. Geography assumed a scientific outlook in undertaking researches with a tilt towards professionalism. New programmes such as Geographic Information System (GIS) and Remote Sensing (RS) were introduced and became important tools in the study of Geography and Environmental Science. Subsequently, the Nigerian Geographical Association (NGA) metamorphosed into the Association of Nigerian Geographers (ANG) with the aim of advancing the study of Geography in Nigeria. The Association of Nigeria Geographers (ANG) has both national and international recognition as a professional association for trained geographers and other persons who are interested in its objectives and functions.

In another regard, the explanation of Ikhuoria (1986) on the development of geography and environmental science disciplines focuses more on the methodological changes. Based on his assumptions, it has moved from the stage of consolidation of geographical ideas, and concepts such as environmentalist and dualism in the post 1950 period to growth of contemporary environmentalist, man and physical relationships, and spatial patterns of interactions, and also paradigm shift from idiographic to nomothetic approaches. Obviously, the stages have moved from the ideological stages to the nomothetic stage. The former focuses majorly on abstract ideas and explanation while the latter considers critically scientific approach to explaining earthly phenomenon and characteristics they exhibit. Lately, emphasis has now been placed on computerized revolution (Morgan and Tidmarsh, 2004), which involves the use of information and communication technologies to explaining concepts, teaching and solving real time problems related to geography and environmental sciences. 


\section{DEVELOPMENT OF INFORMATION COMMUNICATION TECHNOLOGIES (ICTS) IN NIGERIA}

Nigeria has often been described as an 'information-poor' country despite the fact that several sectors have embraced the application of ICT to its production and services. What we refer to as ICT made its first appearance in Nigeria in the early 1960s which is in connection with the 1963 census data (3). Precisely, between the spaces of ten years, the total number of computers was around 25, while 6 were associated with the multinational companies. In 1977, the total number of computer installations has increased to around seventies (Maguire, 1989).

Later in the early 1980s, many universities, governments, and other parastatals such as Joint Admissions and Matriculation Board, National Electric Power Authority, the Nigerian Ports Authority, the Federal Office of Statistics and other commercial banks started showing interest in embedding ICT in their operations (Table 1). After experiencing of its goodies and the effects it can have on productivity, there were significant influxes in computer installations computer business.

Table 1: Milestones in ICT in Nigeria

\begin{tabular}{|l|l|}
\hline Year & Event \\
\hline 1948 & Visible record computer sold to Nigeria Ports Authority by ICL \\
\hline 1949 & NCR Incorporated \\
\hline 1961 & IBM Incorporated \\
\hline 1963 & $\begin{array}{l}\text { Computer hired to assist in the processing of the national census data (operated by } \\
\text { expatriates) }\end{array}$ \\
\hline 1963 & $\begin{array}{l}\text { IBM African Education Centre set up at University College, Ibadan (renamed UI } \\
\text { computing Centre, 1966) }\end{array}$ \\
\hline 1972 & $\begin{array}{l}\text { Computer science courses instituted at University of Lagos, University of Ife and } \\
\text { University of Ibadan }\end{array}$ \\
\hline 1973 & Computers used in 1973 national census \\
\hline 1975 & $\begin{array}{l}\text { Computer science courses instituted at more universities, including the University of } \\
\text { Nigeria, Nsukka }\end{array}$ \\
\hline 1977 & Indigenization decree promulgated \\
\hline 1978 & Computer Association of Nigeria (CAN) inaugurated \\
\hline 1981 & Many more computer vendors established \\
\hline 1982 & Banks begin to computerize \\
\hline 1983 & Import licensing started \\
\hline 1984 & First microcomputer exhibition at Lagos by Ogis \& Ododo \\
\hline 1985 & $\begin{array}{l}\text { Committee of Directors of Nigerian Universities Computing Centres (CDNUCC) } \\
\text { Inaugurated }\end{array}$ \\
\hline 1987 & NNPC optical fibre computer communication network \\
\hline 1992 & Creation and Establishment of the Nigerian Communications Commission (NCC) \\
\hline 1996 & Internet (with full operation in 1998) \\
\hline 2001 & Over 150 ISPs licensed by the Nigerian Communications Commission (NCC) \\
\hline
\end{tabular}




\section{INTEGRATING ICT IN GEOGRAPHY AND ENVIRONMENTAL SCIENCES}

There is no doubt that several attempts have been made by researchers to conceptualize geography and environmental Sciences. While majority are short-lived or never came to limelight, some have made relevant success. One of the notable ones is found in the work of Eratosthenes, in 276-194 BC who described Geography as a discipline that writes about the earth surface. His work marked remarkable success majorly in the field of mathematical geography and specifically in the area of location and measurement of accurate distance. The field of Geography and other environmental sciences study human and nature in such that it attempts to give explanations to their spatial distribution on earth. To achieve this it is important to study the processes and systems that underlie their existence.

The fields of physical geography deals with the physical structure of earth surface encompass; Geomorphology, Geology, Climatology, Biogeography, Soil Geography, Hydrology, Meteorology etc (Figure 1). Human geography on the other hand emphasizes on the place of human on the earth surface. It relates with how human beings live and how they make their living. The field can be further subdivided into settlement geography, urban geography, population geography, economic geography, transport geography etc. Regional Geography in some cases is merged with the field of human geography; it deals with vast land masses into regions and environment to which each state belong. It also covers the physical settings of regions, ethnic groups, resources, economic activities etc. Spatial Science came to limelight with evolution of information technology. This is one of the major aspects of geography that has seen notable success in the application of ICT. The fields include cartography, remote sensing and geographic information system. The complexity involved in this discipline has led to establishment of branches of various specializations such as Physical Geography, Human Geography, Regional Geography and Spatial Science.

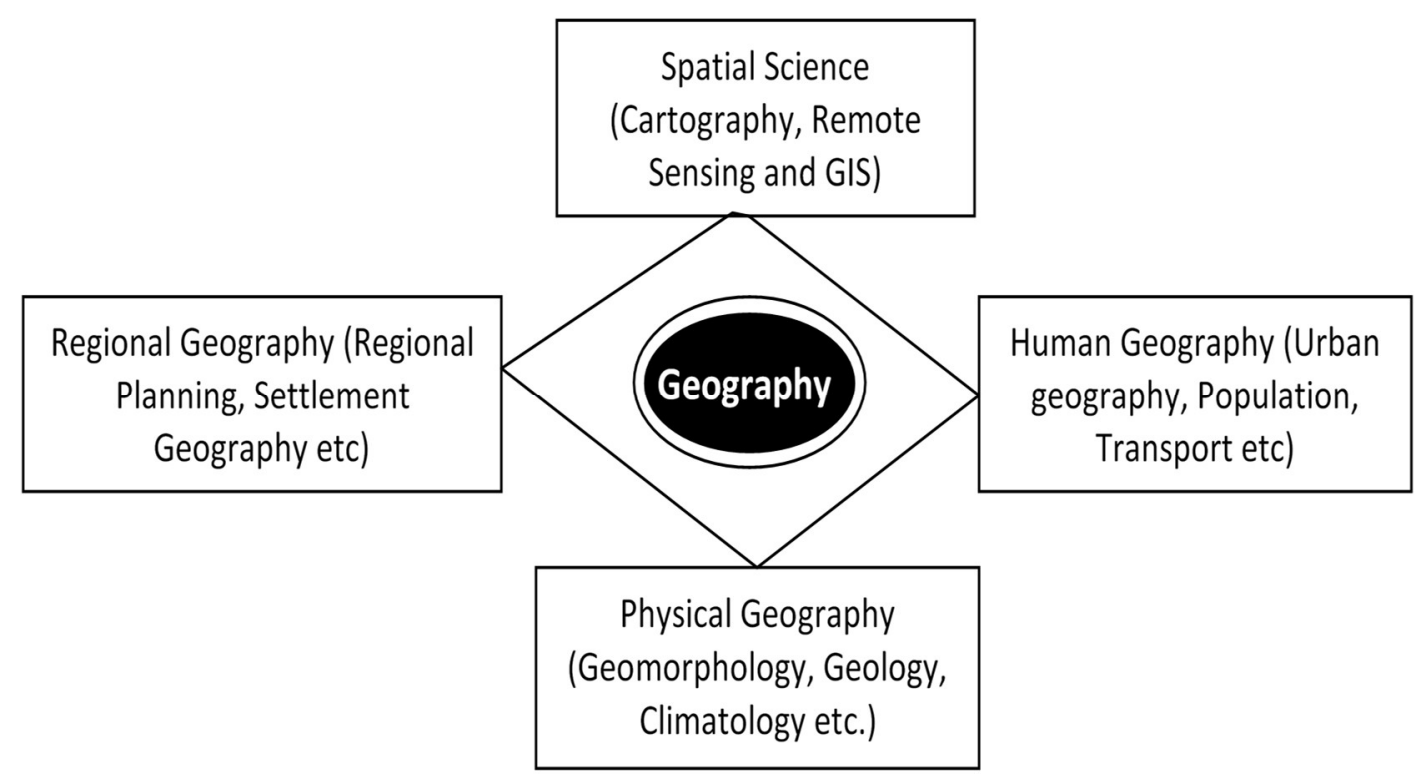

Figure 1: Fields of Geography and Environmental Sciences 
The integration of ICT in Geography and Environmental Sciences in Nigeria has not been adequately exploited, despite the fact that most of the developed nations have experienced notable developments in these areas most especially in the field of spatial sciences. Several top notch computer software have been designed in the collection, manipulation and analysis of data in these fields. Little efforts have been made in integrating ICT in other fields. One important question that comes to mind when considering how ICT can influence research and development in Geography is 'in what way can ICT be integrated?' This quickly brings to mind the need for reliable data in these fields. Data is important because it forms the basis for the knowledge that can be garnered in any field and also the knowledge that can be obtained from such.

The difficulty lies in the approach that needs to be taken and how to embed certain principles in designing both hardware and software components to meeting researchers and professionals needs in the fields of geography. If for instance a researcher in the field of human geography needs to find out how a particular means of transportation has influenced the livelihood of individuals and also considering their level of vulnerability to vehicular hazards. It is almost impossible to give a succinct and dependable assessment. Such researcher will be compelled to give unreliable prediction based on the data collected. To carry out such interesting research needs proper application of ICT tools or probably secondary data of such exist.

To this end, there is need to give a holistic approach to the designing data collection tools for each field. The field of physical geography can be quite different as there can be electronic and non-electronic devices which can be used in the area of data collection. However, if there is need to improve on such, subsequent tools that need to be designed need to focus on each field and not just a particular data in a field. If a researcher needs to collect climate data (temperature, relative humidity, precipitation, sunshine etc) such will need more than one instrument, proper integration of ICT from a holistic approach will tend to ensure that these variables are measured with just a single instrument and data are adequately captured in such a way that the relationships are easily determined. This will broaden the coverage of research and development in the field of Geography and Environmental management and also help researchers to cover more purpose in their studies.

Data storage and management is also vital when considering how to integrate ICT in geographical studies. For instance, in studying trend or change analysis, the holistic way of integrating ICT in geographical studies will ensure that changes are easily noted. This is so because when climate data are stored over a period of time, then it becomes easy to compare with others. Meteorologists and Climatologists will then be embedded with proper tools to make more accurate predictions. Cloud computing is a better approach to storing and managing information. Cloud computing has also given internet users an edge over data loss. This approach has been widely used in storing of vital geographic data in the developed world compared to places like Nigeria where there are certain governmental organizations that still depends on recording of such data on hard sheets.

To make sustainable decision, policy recommendations and implementation, there is need for good and reliable data analysis and interpretation. This area has experienced impressive development and no doubt, exploits have been made. With increasing use of computer analysis software, it is almost becoming trivial task in analyzing geographical data. Both statistical and spatial analysis is very important in the field of Geography and researchers have exploited these areas, howbeit, much is yet to be achieved. 
This is because so many Nigerian geographical professionals and researchers make use of the wrong tools or wrong techniques in analyzing their data, subsequently leading to wrong decisions. Hence, there the need to properly understand how these tools can be applied, and when to be used in analyzing geographical data.

\section{PROBLEMS OF INTEGRATING ICT IN GEOGRAPHY AND ENVIRONMENTAL SCIENCES IN NIGERIA}

The major problem associated with integrating ICT in Geography and Environmental Sciences in Nigeria includes;

i. Low technical know-how: The level of knowhow in most of the ICT tools used in the country is still low. Significant number of educational personnel and professionals of Geography and Environmental sciences in Nigeria have little or no knowledge of the use of certain software or technological resources available to teach and carry out research. Furthermore, most schools lack computers, some hardware and software are out-ofdate, there is lack of resources for development of teachers skills which further leads to increase in the lack of basic skills in using ICT tools. This therefore limits their ability to carry out cutting-edge research and make sustainable decisions; some have to rely on commercial data analysts whose knowledge of geography is below

ii. Government's attitude towards ICT development: Governments ministry and agencies that oversee development in the area of information have done little to improve the condition of ICT in the country. Most of the projects meant to improve this condition are left in the hands of non-professionals, this is so because every aspect of the economy has been politicized and only those that can find their way get it. For instance, where a Minister of Information does not have a background related to information science, it becomes difficult for such personnel to make vital decision that can influence growth in ICT.

iii. Poor funding for research and manpower development: Most teachers do not have the ICT skills they need to make quality research; at the same time little or nothing is done about it. Research is not what it should be in the country; most researches are only carried out by teachers for their own consumption. The government shows little or no interest in the area of research, the effect of such is that adequate funding is not provided to researchers, subsequently inhibiting them from carrying out quality research towards sustainable development.

iv. Poor infrastructure: it is no gainsaying that ICT can only thrive and improve where there is proper infrastructure. The epileptic nature of power supply in the country is a major problem to integrating ICT. In some cases, researchers have to depend on alternative power sources to carry out research which can be costly and at times discouraging.

vi. Reluctant attitude of teachers to accept new technologies: it is worth noting that, acceptance precedes integration, if ICT must be proper integrated in teaching and learning of geography and environmental science, the teachers must be willing to accept such. Unfortunately, teachers have been reluctant to meet up with the use of new technologies in instructional settings. In some cases trainings are being provided while some intentionally do not attend such training. Some believe that computers are not meant for their generation and that younger ones should take up the roles. No doubt this attitude affects what they pass on to learners and the ignorance can continue to persist. 


\section{CONCLUSION/SUGGESTIONS}

It was discovered from this study that there is strong need for integration of ICT in the field of geography and environmental sciences most especially in the teaching and learning process. Therefore, it is important to understand and implement of emerging technologies that will further influence the knowledge, applicability and research in the field. Government needs to properly equip schools and institutions with up-to-date technologies and also provide training that will place the teachers at the same level with their foreign counterparts. Teachers also need to take advantage of ICT resources made available at institutions and ensure they attend trainings and, where there is no training, teachers should consider enrolling themselves in private sessions or self-training from internet resources. Furthermore, Government should properly fund research in the area of ICT application and innovations in the field of geography and environmental science, while also providing adequate infrastructures such as stable electricity for ICT development.

\section{REFERENCES}

1. Gadzama, W.A, Katuka, J.I., Dalhatu, B.L., Abali, A.M. \& Maigana, A.N. (2016). The challenges facing successful integration of ICT in teaching and learning in public secondary schools in Nigeria. Journal of Information Technology, 3(4), 1-11.

2. Ikhuoria, I. A. (1986).The Nigerian school of geography, Geo Journal, 12 (1), 103-105.

3. Kondra, I. (2020). Use of IT in higher education: Studies in Indian Place Names. UGC Care Journal India, 40: 280.

4. Maguire, D. (1989). Computers in geography. Longman: London.

5. Mbodila, Jones \& Muhandji (2013). Integration of ICT in Education: Key Challenges. Scholarly Journal of Mathematics and Computer Science, 2(5), 54.60.

6. Mbodila, M and Kikunga M. (2012). The use of ICT in education: A comparison of traditional pedagogy and emerging pedagogy enabled by ICT's. Proceedings of the 11th International Conference on Frontiers in Education (FECS'12). Las Vega, Nevada, USA.

7. Morgan, J. \& Tidmarsh, C. (2004). Reconceptualizing ICT in geography teaching. Education, Communication \& Information, 4(1), 177-192.

8. Nyandiere, C. (2006). Increasing role of computer-based information system in the management of higher education institutions. Proceedings of Annual Strathmore University ICT Conference.

9. Ojo, J. G. A. (1978). Thirty years of geographic thought in Nigeria. The Nigerian Geographical Journal, (21), pp. 3-23.

10. Okpala, J. (1990). Geography in general education in Nigeria. GeoJournal, 20(1) 37-43. 
11. Ololube, N. P., Ubogu, A.E. \& Ossai, A.G. (2011). ICT and distance education in Nigeria: A review of literature and account. $2^{\text {nd }}$ international Open and Distance Learning (IODL) symposium.

12. Sada, P. O. (1978). Growth and trend of geographical research in Nigeria. Nigerian Geographical Journal, 2, p.8.

13. World Bank. (2009b). Education in Pakistan: Keys Challenges. http://www.worldbank.org.pk/website/external/countries/southasiaext/pakistainext 